\title{
PENGARUH PEMBERIAN SUP JAMUR TIRAM PUTIH (Pleurotus ostreatus) TERHADAP KADAR TRIGLISERIDA PADA SUBJEK OBESITAS
}

\author{
Fiqhi Cahyaningrum Rahmawati, Hesti Murwani Rahayuningsih ${ }^{*}$
}

\author{
Program Studi Ilmu Gizi Fakultas Kedokteran Universitas Diponegoro \\ Jl.Dr.Sutomo No.18, Semarang, Telp (024) 8453708, Email : gizifk@undip.ac.id
}

\begin{abstract}
Background: There were strong association between central obesity and hypertriglyceridemia. Hypertriglyceridemia was defined as an abnormal concentration of triglyceride in the blood and has been associated with atherosclerosis, cardiovascular disease, and acute pancreatitis. Beta glucan as a soluble fiber in oyster mushroom (Pleurotus ostreatus) reduced on triglyceride levels. This study aimed to determine the effect of Pleurotus ostreatus on triglyceride levels in obesity subject.

Methods : This research was pre experimental study with one group pre-test post-test design. Total of 15 subjects (6 male, 9 female; 40-50 years) with triglyceride level $\geq 100-199 \mathrm{mg} /$ dl were consumed 1,21 $/ \mathrm{kg}$ bw/day of oyster mushroom during 21 days. Blood was collected after an overnight fast. Serum triglyceride was measured with GPOPAP method. Intake of total energy, simple carbohydrate, saturated fatty acid, and fiber was measured with food recall 24 hour form. Shapiro Wilk was used to analyze normality of the data. Statistical analyzes include dependent t-test and wilcoxon.

Result : Mean of triglyceride levels before intervention was 152,13+25,71 $\mathrm{mg} / \mathrm{dl}$. Mean of triglyceride levels after intervention was 116,00 $\pm 30,62 \mathrm{mg} / \mathrm{dl}$. There was effect of consumption 1,21 g/kgbw/day of oyster mushroom soup on triglyceride levels $(p=0,002)$. There were no different intake of total energy, simple carbohydrate, SFA, and fiber in before and after intervention. There were different body weight and waist circumference in before and after intervention.
\end{abstract}

Conclusion : Consumption of 1,21 g/kgbw Pleurotus ostreatus soup reduce on triglyceride levels in obesity subject significantly.

Keyword : oyster mushroom; beta glucan; hypertriglyceridemia; obesity

\section{ABSTRAK}

Latar Belakang : Obesitas sentral berkaitan erat dengan kejadian hipertrigliseridemia. Hipertrigliseridemia didefinisikan sebagai abnormalnya kadar trigliserida dalam darah, dan berhubungan dengan kejadian aterosklerosis, penyakit jantung, dan pankreatitis akut. Jamur tiram putih mengandung Beta Glukan, yaitu serat larut air yang dapat menurunkan kadar trigliserida. Penelitian ini bertujuan untuk mengetahui pengaruh pemberian sup jamur tiram putih (Pleurotus ostreatus) terhadap kadar trigliserida pada subjek obesitas.

Metode : Jenis penelitian adalah pre experiment dengan rancangan one group pre test - post test. Subjek 15 orang terdiri dari 6 orang pria dan 9 orang wanita obesitas berusia 40-50 tahun dengan kadar trigliserida $\geq 100 \mathrm{mg} / \mathrm{dl}$. Subjek mendapat 1,21 g/kgbb/hari jamur tiram putih dalam bentuk sup jamur tiram putih selama 21 hari. Metode GPO-PAP digunakan untuk menganalisis kadar trigliserida, darah diambil setelah subjek berpuasa selama 10 jam. Asupan zat gizi subjek sebelum dan selama penelitian dicatat menggunakan formulir food recall 24 jam. Uji normalitas menggunakan Shapiro Wilk. Analisis statistik menggunakan dependent t-test dan wilcoxon.

Hasil : Rerata kadar trigliserida subjek sebelum intervensi yaitu 152,13+25,71 mg/dl. Rerata kadar trigliserida setelah intervensi yaitu 116,00 $\pm 30,62 \mathrm{mg} / \mathrm{dl}$. Konsumsi sup jamur tiram putih dengan dosis $1,21 \mathrm{~g} / \mathrm{kgbb} / \mathrm{hari}$ berpengaruh terhadap penurunan kadar trigliserida $(p=0,002)$. Tidak terdapat perbedaan rerata asupan energi total, karbohidrat sederhana, lemak jenuh, dan serat sebelum dan selama penelitian. Terdapat perbedaan berat badan dan lingkar pinggang sebelum dan selama penelitian.

Simpulan : Konsumsi sup jamur tiram putih 1,21 g/kgbb dapat menurunkan kadar trigliserida pada subjek obesitas secara bermakna.

Kata kunci : jamur tiram putih; beta glukan; hipertrigliseridemia; obesitas

\section{PENDAHULUAN}

Obesitas adalah keadaan berlebihnya lemak di jaringan adiposa atau lemak tubuh. ${ }^{1}$ Obesitas lebih efektif didefinisikan dengan menilai hubungan ke arah morbiditas atau kematian karena beberapa individu (seperti atlet) yang mempunyai berat badan melebihi standar berdasarkan pengukuran indeks massa tubuh, tidak mengalami peningkatan adipositas. $^{2}$ Kelebihan lemak dalam tubuh dapat terjadi di lemak subkutan atau biasa disebut obesitas general dan lemak viseral atau obesitas sentral. ${ }^{3}$

Prevalensi obesitas pada penduduk dewasa di Indonesia berusia lebih dari 18 tahun mengalami peningkatan. Prevalensi obesitas pada pria tahun

\footnotetext{
${ }^{*}$ Penulis Penanggungjawab
} 
2007 13,9\%, tahun 2010 7,8\%, dan tahun 2013 19,7 $\%$. Prevalensi obesitas pada wanita tahun 2007 13,9\%, tahun 2010 15,5\%, dan tahun 2013 32,9\%. ${ }^{3}$ Sedangkan prevalensi obesitas umum di kota Semarang sendiri pada tahun 2007 sebesar $20,5 \%$ dengan $18,6 \%$ pria dan $22,3 \%$ wanita. $^{4}$

Penderita obesitas sentral sering mengalami hipertrigliseridemia. ${ }^{2,5,6}$ Hipertrigliseridemia atau kadar trigliserida yang tinggi berkaitan dengan pembentukan plak pada dinding pembuluh darah, meningkatkan kadar Low Density Lipoprotein (LDL) dan menurunkan kadar HDL sehingga meningkatkan risiko terjadinya penyakit arteri koroner. ${ }^{7}$ Kadar trigliserida yang sangat tinggi (> $500 \mathrm{mg} / \mathrm{dl}$ ) dapat berisiko menjadi pankreatitis akut karena terjadi gangguan dalam sekresi enzim lipase termasuk lipoprotein lipase oleh pankreas. ${ }^{8} \mathrm{Di}$ samping itu, pasien hipertrigliseridemia lebih sering mengalami sindrom metabolik (seperti obesitas abdominal, hipertensi, resistensi insulin, kadar HDL rendah, dan kadar trigliserida tinggi). ${ }^{9}$

Trigliserida atau triasilgliserol merupakan hasil kondensasi dari satu molekul gliserol dengan tiga molekul asam lemak yang diproduksi di dalam hati. ${ }^{10}$ American Heart Association (AHA) pada tahun 2011 telah menetapkan standar baru terhadap nilai optimal kadar trigliserida menjadi $<100$ $\mathrm{mg} / \mathrm{dL} .{ }^{11}$ Kadar trigliserida dipengaruhi oleh usia, asupan, dan aktivitas fisik. Asupan lemak jenuh dan asupan karbohidrat sederhana akan disimpan sebagai trigliserida di bawah kulit dan di organorgan lain. ${ }^{10}$ Kelebihan asupan lemak jenuh dan asupan karbohidrat sederhana dapat meningkatkan kadar trigliserida terutama pada penderita obesitas sentral. Usia 40-50 tahun adalah usia yang sering mengalami peningkatan kadar trigliserida dan risiko penyakit jantung karena berkurangnya hormon reproduktif baik pada pria maupun wanita. ${ }^{9,11,12}$

Perlu pencegahan kenaikan kadar trigliserida ketika tahap hipertrigliseridemia ringan $(100-199 \mathrm{mg} / \mathrm{dl})$ untuk menurunkan risiko penyakit jantung koroner. Cara yang aman untuk menurunkan kadar trigliserida darah tanpa menimbulkan efek samping antara lain dengan modifikasi diet rendah lemak jenuh dan karbohidrat sederhana serta diperlukan juga mengkonsumsi makanan yang dapat mengurangi kadar trigliserida dalam darah sehingga diet yang dilakukan menjadi lebih efektif. ${ }^{13}$ Modifikasi diet yang direkomendasikan adalah dengan mengkonsumsi 25-40 gram serat makanan yang meliputi 7-13 gram serat larut perhari minimal 3 minggu untuk menurunkan kadar trigliserida. ${ }^{14}$

Jamur tiram putih (Pleurotus ostreatus) merupakan makanan yang cukup populer di masyarakat, murah, mudah dibudidayakan, dan diolah bila dibandingkan dengan jenis jamur lainnya. Jamur tiram putih juga aman dikonsumsi setiap hari. ${ }^{15}$ Serat larut air berupa beta glukan yang berasal dari dinding sel jamur tiram putih dapat menurunkan kadar trigliserida dengan jalan mengurangi dan memperlambat absorbsi lemak dan glukosa. ${ }^{16}$ Beta glukan juga meningkatkan ekskresi asam empedu yang dapat mengganggu penyerapan trigliserida sehingga kadar trigliserida menurun. ${ }^{17}$

Penelitian pertama pada manusia yaitu pada remaja selama 21 hari menunjukkan serat dalam jamur tiram putih yang diberikan dalam bentuk sup mengandung 300 gram jamur tiram putih dapat menurunkan kadar trigliserida, LDL teroksidasi, dan kolesterol total secara bermakna. ${ }^{18}$ Penelitian lain pada hamster selama 2 minggu mengenai efek antihiperkolesterol ekstrak alkali $\beta$-glukan jamur tiram putih dengan dosis $50,4 \mathrm{mg} / \mathrm{kgbb}$ atau setara dengan $0,11 \mathrm{~g} / \mathrm{kg}$ bb setelah dikonversikan untuk perhitungan pada manusia menunjukkan penurunan kadar kolesterol total, trigliserida, dan LDL hamster secara signifikan. ${ }^{19}$

Jamur tiram putih mengandung serat larut beta glukan $9,1 \mathrm{~g} / 100 \mathrm{~g}$ dan tahan terhadap suhu pemanasan $100^{\circ} \mathrm{C}$ selama 3 jam. ${ }^{19,20,21}$ Pengolahan jamur tiram putih yang mudah dalam pengolahan dan mudah dikonsumsi adalah dalam bentuk sup. Bentuk pengolahan ini tidak memerlukan tambahan minyak seperti pada pengolahan digoreng yang justru dapat meningkatkan kadar trigliserida. Selain itu, pengolahan sup ditambahkan bumbu seperti bawang putih dan lada yang juga dapat membantu menurunkan kadar trigliserida. Oleh karena itu, penelitian ini akan menggunakan dosis beta glukan $0,11 \mathrm{gram} / \mathrm{kg}$ berat badan setara dengan dosis jamur tiram putih yang diberikan sebanyak 1,21 gram $/ \mathrm{kg}$ berat badan selama 21 hari dengan metode pemberian berupa sup sehingga diharapkan dapat menurunkan kadar trigliserida pada subjek obesitas.

Pengambilan subjek penelitian dilakukan di wilayah Kelurahan Meteseh Semarang karena termasuk wilayah urban dimana kejadian obesitas dan peningkatan kadar trigliserida pada orang dewasa baik di wilayah urban maupun pusat kota hampir sama dan ada kecenderungan yang terus meningkat pada wilayah urban dengan aktivitas fisik yang rendah. ${ }^{3}$ Guru dan karyawan adalah profesi yang mempunyai aktivitas yang rendah sehingga diharapkan dapat mewakili kelompok dengan aktivitas fisik rendah. Subjek yang diteliti adalah kelompok umur 40 sampai 50 tahun karena kelompok umur tersebut sering terjadi peningkatan kadar trigliserida dan risiko penyakit jantung akibat berkurangnya hormon reproduktif., ${ }^{9}$ 
Berdasarkan uraian tersebut, peneliti ingin melakukan penelitian tentang pengaruh pemberian sup jamur tiram putih (pleurotus ostreatus) terhadap kadar trigliserida pada subjek obesitas. Tujuan dalam penelitian ini adalah membuktikan pengaruh pemberian sup jamur tiram putih (pleurotus ostreatus) terhadap kadar trigliserida pada subjek obesitas.

\section{METODE}

Penelitian ini merupakan penelitian pre experiment dengan rancangan one group pre test post test. Variabel bebas dalam penelitian ini adalah pemberian sup jamur tiram putih, sementara variabel terikat adalah kadar trigliserida. Variabel perancu dalam penelitian ini adalah asupan energi total, karbohidrat sederhana, lemak jenuh, dan serat.

Subjek penelitian adalah guru dan karyawan SMP negeri 33 Semarang. Kriteria inklusi penelitian ini memiliki kadar trigliserida 100-199 $\mathrm{mg} / \mathrm{dl}$, usia 40-50 tahun, lingkar pinggang di atas normal (laki-laki $\geq 90 \mathrm{~cm}$ dan wanita $\geq 80 \mathrm{~cm}$ ) menurut WHO Asia Pasifik, tidak sedang mengonsumsi obat penurun kadar trigliserida selama penelitian, tidak merokok, tidak alergi dan intoleransi terhadap jamur tiram putih, tidak dalam keadaan sakit atau dalam perawatan dokter berkaitan dengan penyakit jantung koroner, diabetes melitus, dan penyakit kronik lainnya. Subjek dinyatakan keluar dari penelitian apabila tidak mengikuti prosedur penelitian, mengundurkan diri, atau meninggal dunia.

Perhitungan subjek penelitian menggunakan rumus uji hipotesis terhadap rerata sampel tunggal dan dibutuhkan sebanyak 10 subjek. Penentuan subjek penelitian menggunakan metode consecutive sampling. Skrining yang dilakukan pada 72 orang guru dan karyawan didapatkan 26 orang mempunyai status gizi obesitas. Sedangkan yang bersedia diambil darahnya untuk proses skrining awal sebanyak 24 orang. Pada akhir skrining, sebanyak 19 subjek memenuhi kriteria inklusi dan seluruhnya diikutkan penelitian karena untuk menghindari kekurangan sampel apabila banyak terjadi drop out. Selama penelitian ada 4 subjek penelitian yang mengalami drop out sehingga tersisa 15 orang yang dapat mengikuti penelitian sampai selesai. Penyebab drop out adalah tiga subjek penelitian mengikuti pelatihan di luar kota dan satu subjek penelitian merasakan keberatan melanjutkan penelitian.

Pemberian sup jamur tiram putih dilakukan selama 21 hari. Asupan zat gizi sehari-hari subjek penelitian tidak dikontrol. Pencatatan makan dilakukan sebelum dan selama intervensi. Kepatuhan subjek mengonsumsi sup jamur tiram putih dicatat dengan menggunakan formulir kepatuhan. Cara membuat sup jamur tiram putih adalah jamur tiram putih segar sebanyak 1,21 gram/kgbb dicuci bersih dengan air mengalir. Kemudian dimasukkan ke dalam panci dengan bumbu sup yang sudah dihaluskan yaitu bawang putih $0,2 \mathrm{mg} / \mathrm{gram}$ jamur, lada $0,3 \mathrm{mg} / \mathrm{gram}$ jamur, dan garam $0,16 \mathrm{mg} /$ gram jamur. Ditambahkan air sampai $50 \mathrm{ml}$ dan dimasak selama 5 menit.

Kadar trigliserida dianalisis dengan menggunakan metode enzimatik GPO-PAP. Sampel darah diambil oleh petugas laboratorium setelah subjek berpuasa selama \pm 10 jam. Pengukuran lingkar pinggang sebelum dan sesudah intervensi dengan menggunakan pita ukur. Pengukuran berat badan sebelum dan sesudah intervensi dengan menggunakan timbangan digital. Aktivitas fisik hanya diukur diawal penelitian menggunakan recall aktivitas 1x24 jam dengan menjumlahkan delta Physical Activity Level (PAL) untuk setiap aktivitas dalam 1 hari berdasarkan tabel aktivitas fisik dengan nilai Thermic Effect of Food (TEF) sebesar 1,1 sehingga didapatkan nilai PAL sesuai kategori aktivitas fisik sedentary (1-1,39), rendah (1,4-1,59), tinggi $(1,6-1,89)$, dan sangat tinggi $(1,9-2,5)$. Data asupan zat gizi di luar asupan sup jamur tiram putih yang meliputi asupan energi total, asam lemak jenuh, karbohidrat sederhana, dan serat diperoleh dari konsumsi makanan dan minuman subjek penelitian melalui wawancara sebelum dan selama intervensi menggunakan formulir food recall 24 jam. Data asupan zat gizi subjek dianalisis menggunakan program nutrisurvey.

Uji normalitas data menggunakan uji Shapiro-Wilk. Perbedaan kadar trigliserida, berat badan, lingkar pinggang sebelum dan sesudah intervensi, asupan makan sebelum dan selama intervensi diuji menggunakan dependent t-test karena data berdistribusi normal. Perbedaan berat badan sebelum dan sesudah intervensi diuji menggunakan wilcoxon test karena data berdistribusi tidak normal. Analisis variabel perancu selama penelitian seperti asupan energi total, karbohidrat sederhana, asam lemak jenuh, dan serat menggunakan uji korelasi pearson dan regresi.

\section{HASIL PENELITIAN \\ Karakteristik subjek}

Karakteristik subjek yang terdiri dari berat badan, lingkar pinggang, dan aktivitas fisik disajikan dalam Tabel 1. 
Tabel 1. Karakteristik subjek

\begin{tabular}{lcccc}
\hline \multicolumn{1}{c}{ Variabel } & Total & $\begin{array}{c}\text { Sebelum } \\
\text { Intervensi } \\
\text { (rerata } \pm \text { s.b) }\end{array}$ & $\begin{array}{c}\text { Setelah } \\
\text { Intervensi } \\
\text { (rerata } \pm \text { s.b) }\end{array}$ & $p$ \\
\hline Berat badan & 15 & $69,75 \pm 1,01$ & $68,71 \pm 1,00$ & $0,001^{*}$ \\
\hline Lingkar Pinggang awal (cm) & 9 & $88,33 \pm 6,28$ & $86,52 \pm 5,80$ & $0,002 * *$ \\
Wanita $\geq 80 \mathrm{~cm}$ & 6 & $95,75 \pm 3,55$ & $95,17 \pm 3,05$ & $0,043^{* *}$ \\
Laki-laki $\geq 90 \mathrm{~cm}$ & 15 & $1,48 \pm 0,05$ & - & -
\end{tabular}

*Uji Wilcoxon

**Uji t berpasangan

Terdapat perbedaan berat badan sebelum dan setelah dilakukan intervensi $(\mathrm{p}<0,05)$. Terdapat perbedaan rerata lingkar pinggang sebelum dan setelah dilakukan intervensi baik pada subjek pria maupun subjek wanita $(\mathrm{p}<0,05)$. Semua nilai Physical Activity Level (PAL) subjek sebelum penelitian termasuk kategori aktivitas rendah (nilai PAL 1,4-1,59) dengan rerata 1,48 $\pm 0,05$.

Pengaruh pemberian sup jamur tiram putih terhadap kadar trigliserida

Rerata kadar trigliserida awal penelitian yaitu $152,13 \pm 25,71$ dan rerata kadar trigliserida akhir penelitian yaitu $116,00 \pm 30,08$. Perbedaan rerata kadar trigliserida awal dan akhir penelitian yaitu $-36,13 \pm 37,79$ atau terjadi penurunan kadar trigliserida sebesar $23,75 \%$. Uji t berpasangan menghasilkan nilai significancy $=0,002$ artinya ada perbedaan rerata kadar trigliserida sebelum dan setelah intervensi sup jamur tiram putih selama 21 hari $(\mathrm{P}<0,05)$.

\section{Perbedaan asupan zat gizi sebelum dan selama intervensi}

Uji beda asupan zat gizi di luar asupan sup jamur tiram putih sebelum dan selama intervensi menunjukkan tidak ada perbedaan asupan total energi, lemak jenuh, karbohidrat sederhana, dan serat sebelum dan selama intervensi $(p>0,05)$. Persen kecukupan asupan total energi, lemak jenuh, dan karbohidrat sederhana mengalami penurunan, sedangkan persen kecukupan serat mengalami peningkatan selama penelitian.

Selama penelitian, terdapat 10 subjek penelitian mengalami penurunan asupan energi total dan 5 subjek mengalami peningkatan asupan energi total. Terdapat 8 subjek penelitian mengalami penurunan asupan lemak jenuh dan 7 subjek mengalami peningkatan asupan lemak jenuh. Terdapat 10 subjek penelitian mengalami penurunan asupan karbohidrat sederhana dan 5 subjek mengalami peningkatan asupan karbohidrat sederhana. Terdapat 8 subjek mengalami peningkatan asupan serat dan 7 subjek mengalami penurunan asupan serat.

Uji korelasi variabel perancu yaitu asupan zat gizi yang berkaitan dengan kadar trigliserida adalah asupan energi total, karbohidrat sederhana, asam lemak jenuh, dan serat. Setelah dilakukan uji pearson menunjukkan tidak ada hubungan asupan zat gizi selama intervensi dengan kadar trigliserida setelah intervensi dan hasil uji juga tidak memenuhi syarat untuk diuji regresi karena nilai sig >0,25.

Tabel 2. Perbedaan asupan makan sebelum dan selama intervensi

\begin{tabular}{lccccc}
\hline \multicolumn{1}{c}{ Variabel } & $\mathrm{n}$ & Rerata \pm s.b. & $\begin{array}{c}\text { Persen } \\
\text { kecukupan }\end{array}$ & $\begin{array}{c}\text { Perbedaan Rerata } \\
\pm \text { s.b. }\end{array}$ & $p$ \\
\hline Energi awal & 15 & $1.660,3 \pm 396,24$ & $100,82 \pm 22,06$ & $-123,47 \pm 224,80$ & $0,052^{*}$ \\
Energi selama intervensi & 15 & $1.536,8 \pm 368,58$ & $91,61 \pm 19,19$ & & \\
\hline $\begin{array}{l}\text { Lemak jenuh awal } \\
\text { Lemak jenuh selama }\end{array}$ & 15 & $24,73 \pm 11,33$ & $136,15 \pm 66,73$ & $-2,24 \pm 11,10$ & $0,447^{*}$ \\
intervensi & 15 & $22,49 \pm 7,26$ & $122,64 \pm 36,24$ & & \\
\hline $\begin{array}{l}\text { Karbohidrat sederhana } \\
\text { awal }\end{array}$ & 15 & $36.66 \pm 19.13$ & $88,04 \pm 42,89$ & $-4,84 \pm 13.46$ & $0,186^{*}$ \\
$\begin{array}{l}\text { Karbohidrat sederhana } \\
\text { selama intervensi }\end{array}$ & 15 & $31.83 \pm 15.51$ & $68,11 \pm 31,40$ & & \\
\hline $\begin{array}{l}\text { Serat awal } \\
\text { Serat selama intervensi }\end{array}$ & 15 & $8.66 \pm 3,35$ & $43,30 \pm 16,76$ & $0,62 \pm 1,89$ & $0,227^{*}$ \\
\hline
\end{tabular}

*Uji t berpasangan 


\section{Kepatuhan konsumsi sup jamur tiram putih}

Selama penelitian terdapat 4 subjek dari 19 subjek hanya menghabiskan sup jamur tiram putih selama 5 hari sehingga dikeluarkan dari penelitian. Sebanyak 15 subjek menghabiskan sup jamur tiram putih yang diberikan sampai akhir penelitian. Tidak ada efek samping yang ditemukan selama pemberian sup jamur tiram putih.

\section{PEMBAHASAN}

Hasil penelitian ini sesuai dengan hipotesis yaitu ada pengaruh pemberian sup jamur tiram putih terhadap penurunan kadar trigliserida pada subjek obesitas. Kadar trigliserida dipengaruhi oleh beberapa faktor diantaranya usia, status gizi, dan asupan. Risiko hipertrigliseridemia baik pada wanita maupun pada laki-laki meningkat seiring dengan meningkatnya usia. Usia 40-50 tahun merupakan usia yang sering mengalami peningkatan kadar trigliserida dan risiko penyakit jantung karena berkurangnya hormon reproduktif. ${ }^{9,11,12}$ Wanita yang berusia 40-50 tahun memiliki hormon estrogen yang menurun sehingga cenderung mengalami peningkatan kadar trigliserida. Hormon estrogen ini bersifat protektif untuk mencegah meningkatnya kadar trigliserida. ${ }^{22}$ Sedangkan pada pria, peningkatan risiko hipertrigliseridemia seiring dengan bertambahnya usia dikarenakan menurunnya hormon testosteron. ${ }^{23}$

Pengukuran lingkar pinggang merupakan cara paling murah dan sederhana yang dapat digunakan untuk menilai akumulasi massa lemak dalam menentukan obesitas. Penderita obesitas, terutama obesitas abdominal sering mengalami peningkatan kadar trigliserida akibat penumpukan lemak jenuh pada rongga perut. ${ }^{2,6}$ Seluruh subjek dalam penelitian ini mempunyai lingkar pinggang yang melebihi normal (obesitas sentral) dan kadar trigliserida di atas $\geq 100 \mathrm{mg} / \mathrm{dl}$. Hal ini sesuai penelitian di Korea yang menyatakan lingkar pinggang berkaitan erat dengan kejadian hipertrigliseridemia dalam populasi. ${ }^{24}$

Sup jamur tiram putih adalah jamur tiram putih segar yang dimasak dengan penambahan bawang putih, lada, dan garam. Sup mudah diolah dan dikonsumsi. Bentuk pengolahan ini tidak memerlukan tambahan minyak seperti pada bentuk yang digoreng yang justru dapat meningkatkan kadar trigliserida. Selain itu, pengolahan sup ditambahkan bumbu seperti bawang putih dan lada yang juga dapat membantu menurunkan kadar trigliserida.

Dosis bawang putih pada orang dewasa yang dapat digunakan untuk menurunkan kadar trigliserida yaitu 4 gram (satu sampai dua siung) bawang putih mentah per hari atau bentuk tablet 600 mg bubuk bawang putih/hari selama 12 minggu. ${ }^{25}$ Penambahan bawang putih sebagai bumbu ke dalam sup jamur di penelitian ini yaitu $0,2 \mathrm{mg} / \mathrm{g}$ jamur atau $<20 \mathrm{mg}$ perindividu. Penelitian mengenai pengaruh suplementasi ekstrak zat dari lada hitam berupa piperin $40 \mathrm{mg} / \mathrm{kgbb}$ dapat memperbaiki profil lipid tikus melalui mekanisme pengaturan kadar apolipoprotein dan resistensi insulin. Dosis piperin yang dianjurkan adalah 5-15 mg/hari (294 mg lada). ${ }^{26,27}$ Jumlah lada yang diberikan dalam sup jamur tiram putih ini yaitu $<30 \mathrm{mg}$ per individu perhari. Pemberian bawang putih dan lada dalam sup jamur tiram putih ini dapat membantu menurunkan kadar trigliserida.

Asupan zat gizi meliputi asupan energi total, lemak jenuh, karbohidrat sederhana, dan serat merupakan faktor yang ikut berpengaruh terhadap kadar trigliserida. Asupan energi yang berlebihan dalam tubuh akan diubah menjadi trigliserida dan akan disimpan di jaringan adiposa sebagai lemak tubuh. ${ }^{28}$ Selain asupan energi, peningkatan asupan lemak jenuh akan menyebabkan peningkatan aktivitas lipogenesis dan asam lemak bebas yang terbentuk dan berikatan dengan gliserol membentuk triasilgliserol sehingga semakin tinggi konsumsi asam lemak jenuh maka semakin tinggi pula sintesa triasilgliserol di hati dan semakin tinggi kadar trigliserida dalam darah. ${ }^{29}$

Asupan tinggi karbohidrat sederhana dapat meningkatkan jumlah trigliserida yang terdeposit pada jaringan adiposa terutama yang berada dibawah kulit dan di rongga perut. Selain itu, makanan yang tinggi karbohidrat, akan meningkatkan kadar fruktose 2,6 bifosfat sehingga fosfofruktokinase-1 menjadi lebih aktif dan terjadi rangsangan terhadap reaksi glikolisis. Peningkatan reaksi glikolisis akan menyebabkan glukosa yang diubah menjadi asam lemak meningkat dan berikatan dengan gliserol membentuk triasilgliserol sehingga semakin tinggi karbohidrat yang dikonsumsi semakin tinggi kadar trigliserida dalam darah. ${ }^{29}$ Asupan karbohidrat komplek seperti serat berbanding terbalik dengan kadar trigliserida. Asupan serat yang direkomendasikan untuk menurunkan kadar trigliserida adalah 25-40 gram serat makanan yang meliputi 7-13 gram serat larut perhari selama minimal 3 minggu. ${ }^{14}$

Tidak ada perbedaan asupan energi total, karbohidrat sederhana, asam lemak jenuh, dan serat selama penelitian. Pemberian sup jamur tiram putih dengan dosis $1,21 \mathrm{~g} / \mathrm{kgbb} / \mathrm{hari}$ selama 21 hari memberikan pengaruh terhadap penurunan kadar trigliserida $(\mathrm{p}<0,05)$ tanpa diikuti perubahan asupan zat gizi selama penelitian. Namun, tidak semua 
subjek penelitian ini mengalami penurunan kadar trigliserida setelah penelitian, dari 15 subjek yang ikut penelitian ini terdapat 12 subjek mengalami penurunan kadar trigliserida dan 3 subjek mengalami peningkatan kadar trigliserida.

Terdapat 3 subjek yang mengalami kenaikan kadar trigliserida $10-12 \mathrm{mg} / \mathrm{dl}$. Subjek pertama mengalami kenaikan kadar trigliserida sebesar $10 \mathrm{mg} / \mathrm{dl}$. Subjek mengalami penurunan asupan karbohidrat sederhana tetapi juga mengalami peningkatan asupan energi total sebesar $9,65 \mathrm{~g}$, asupan lemak jenuh sebesar 5,45 g, dan penurunan asupan serat 1,8 g. Subjek kedua mengalami kenaikan kadar trigliserida sebesar 10 $\mathrm{mg} / \mathrm{dl}$. Subjek ini mengalami penurunan asupan energi total sebesar 320,25 kkal dan peningkatan asupan serat $1,71 \mathrm{~g}$, tetapi subjek juga mengalami peningkatan asupan lemak jenuh sebesar 12,76 g dan peningkatan asupan karbohidrat sederhana sebesar 7,61 g. Subjek ketiga mengalami kenaikan kadar trigliserida sebesar $12 \mathrm{mg} / \mathrm{dl}$. Subjek ini mengalami penurunan asupan lemak jenuh sebesar $27,55 \mathrm{~g}$ tetapi juga mengalami peningkatan asupan energi total sebesar 94,68 kkal, peningkatan asupan karbohidrat sederhana sebesar 1,7 g, dan penurunan asupan serat sebesar $0,4 \mathrm{~g}$. Hal ini menunjukkan peningkatan asupan energi total, lemak jenuh, karbohidrat sederhana, dan penurunan asupan serat selama penelitian dapat meningkatkan kadar trigliserida meskipun diberikan sup jamur tiram putih.

Terdapat 2 subjek penelitian yang membatasi asupan hingga kurang dari kebutuhan energi basal karena berusaha menurunkan berat badan. Subjek pertama membatasi asupan hingga $65,6 \%$ dari kebutuhan energi basal selama penelitian. Namun, sebelum intervensi asupan energi subjek tersebut memang masih kurang dari kebutuhan energi basalnya $(94,5 \%)$. Subjek kedua asupan energi sebelum dan selama intervensi berkisar $61-67 \%$ dari kebutuhan energi basal. Kedua subjek mengalami penurunan kadar trigliserida dari tinggi sampai normal. Meskipun demikian, pembatasan asupan hingga kurang dari kebutuhan energi basal akan memberikan dampak buruk pada tubuh karena pemenuhan energi basal diperlukan untuk memelihara proses-proses hidup seperti pernafasan, sistem saraf, dan mempertahankan suhu badan. ${ }^{30}$

Terdapat 1 subjek yang membatasi asupan dari total asupan energi yang berlebih (>100\% total energi) menjadi sesuai kebutuhan yang seharusnya dan membatasi asupan karbohidrat sederhana sehingga banyak mengalami penurunan kadar trigliserida yaitu sebesar $120 \mathrm{mg} / \mathrm{dl}$. Hal ini bisa terjadi karena trigliserida merupakan simpanan lemak dalam tubuh, ketika asupan energi rendah, tubuh akan menggunakan simpanan lemak tubuh untuk menghasilkan energi dengan cara meningkatkan pemecahan trigliserida sehingga kadar trigliserida akan menurun. ${ }^{31}$

Jumlah serat larut yang dibutuhkan untuk menurunkan kadar trigliserida yaitu 7-13g/hari selama minimal 3 minggu. ${ }^{17}$ Jamur tiram putih mengandung beta glukan $9,1 \mathrm{~g} / 100 \mathrm{~g}$ dan tahan terhadap suhu pemanasan $100^{\circ} \mathrm{C}$ selama 3 jam. ${ }^{19,20,21}$ Pada penelitian ini, kandungan beta glukan sebagai serat larut dalam sup yang mengandung jamur tiram putih 77-100 gram diperkirakan ada sebesar 7-9,3g/hari sehingga dapat memenuhi kebutuhan serat larut yang dianjurkan. Kandungan beta glukan sebagai serat larut dalam jamur tiram putih dapat berperan dalam penurunan kadar trigliserida dengan jalan mengikat produk pencernaan lemak (asam lemak dan gliserol) lalu mengurangi dan memperlambat absorbsi lemak dan glukosa. ${ }^{16,17}$ Beta glukan dapat meningkatkan ekskresi asam empedu yang berfungsi membantu penyerapan trigliserida. Bila ekskresi asam empedu semakin meningkat, maka penyerapan trigliserida juga akan terganggu, akibatnya dapat menurunkan kadar trigliserida. ${ }^{17}$

Beta glukan sebagai serat larut juga dapat memicu terjadinya penurunan berat badan dan lingkar pinggang. Pada penelitian ini terjadi perbedaan berat badan dan lingkar pinggang subjek sebelum dan selama penelitian. Hal ini sesuai penelitian lain yang dilakukan pada tikus yang diberi diet tinggi lemak dan diintervensi dengan beta glukan yang berasal dari jamur tiram menunjukkan terjadi penurunan berat badan dan kadar trigliserida. ${ }^{32}$ Beta glukan menunda pengosongan lambung sehingga menimbulkan rasa kenyang lebih lama, terjadi penurunan asupan, dan berat badan. ${ }^{33}$

Penurunan berat badan juga dapat dipengaruhi oleh aktivitas fisik. Aktivitas fisik meningkatkan lipolisis dan mobilisasi lemak dari jaringan adiposa menuju otot rangka untuk digunakan sehingga dapat menurunkan simpanan lemak tubuh di jaringan adiposa yang mengakibatkan penurunan berat badan dan lingkar pinggang. ${ }^{34}$ Aktivitas fisik pada penelitian ini hanya diukur diawal penelitian yaitu seluruh subjek mempunyai aktivitas fisik rendah sedangkan selama penelitian tidak dilakukan pengukuran aktivitas fisik. Penurunan berat badan dan lingkar pinggang pada penelitian ini mungkin disebabkan juga oleh perubahan aktivitas fisik subjek selama penelitian. 


\section{SIMPULAN}

Pemberian sup jamur tiram putih dengan dosis $1,21 \mathrm{~g}$ per kilogram berat badan per hari selama 21 hari dapat menurunkan kadar trigliserida pada subjek obesitas secara bermakna.

\section{SARAN}

Penderita hipertrigliseridemia ringan dapat mengonsumsi sup jamur tiram putih sebanyak 1,21 $\mathrm{g} / \mathrm{kgBB}$ perhari sebagai alternatif asupan serat larut untuk menurunkan kadar trigliserida. Diperlukan uji laboratorium untuk mengetahui besar kandungan beta glukan di dalam sup jamur tiram putih. Diperlukan penelitian lebih lanjut mengenai pengaruh asupan sup jamur tiram putih dan aktivitas fisik terhadap kadar trigliserida.

\section{DAFTAR PUSTAKA}

1. Robert DL. Energy Balance and Body Weight. In : Marcia Nelms, Kathryn P. Sucher, Karen Lacey, Sara Long Roth, editors. Nutrition Therapy and pathophysiology. 2nd ed. USA - Wadsworth, Cengage Learning; 2010.p.246.

2. Fauci, Braunwald, Kasper, Hauser, Longo, Jameson, et al. Harrison's Principles of Internal Medicine $17^{\text {th }}$ Edition. USA - McGraw-Hill's Acces Medicine. 2008.

3. Kementerian Kesehatan RI. Riset Kesehatan Dasar. 2013.

4. Laporan Hasil Riset Kesehatan Dasar (RISKESDAS) Nasional 2007.

5. Poirier P, Giles T, Bry G, Hong Y, Stern J, PiSunyer $\mathrm{X}$, et al. Obesity and Cardiovascular Disease: Pathophysiology, Evaluation, and Effect of Weight Loss. Circ. 2006; 113:898-918.

6. Sri H, Eriza F, Dian R. Hubungan Lingkar Pinggang dengan Kadar Trigliserida pada Pasien Rawat Jalan Dislipidemia di Puskesmas Janti Kota Malang. Malang: Jurusan Gizi Fakultas Kedokteran Universitas Brawijaya. 2012.

7. John DB. Hypertriglyceridemia. N Engl J Med 2007;357:1009-17.

8. George Y, Khalid Z, Robert A. Hypertriglyseridemia: Its Etiology, Effects, and Treatment. [review]. CMAJ 2007;176(8).

9. Charles M, Pamela B, Steven M, Steven M. NCEPDefined Metabolic Syndrome, Diabetes, and Prevalence of Coronary Heart Disease Among NHANES III Participants Age 50 Years and Older. American Diabetes Association. Vol 52 Mei 2003.

10. Kathleen MB, Mayes PA. Metabolisme Asilgliserol dan Sfingolipid. In: Murray RK, Granner DK, Mayes PA, Rodwell VW, editors. Biokimia Harper. Edisi 27. Jakarta: Penerbit Buku Kedokteran EGC;2012.p.217-19.

11. Miller M, Stone N, Ballantyne C, Bittner V, Criqui $\mathrm{M}$, Ginsberg $\mathrm{H}$, et al. Triglycerides and Cardiovascular Disease: A Scientific Statement
From the American Heart Assosiation. Circulation; 2011.p.2292 - 2333.

12. Executive Summary of the Third Report of the National Cholesterol Education Program (NCEP) Expert Panel on Detection, Evaluation, and Treatment of High Blood Cholesterol in Adults (Adult Treatment Panel III). 2002.

13. Anonymous. Cara Alami Menurunkan Kolesterol [online]. 2011. Available from: URL: http//www.dokter-online.org.

14. Zeljko R, Alberici L, Guy D, Ian G, Marja T, Olov $\mathrm{W}$, et al. ESC/EAS Guidlines for Management of Dyslipidaemias. The Task force for the Management of Dyslipidaemias of the European Society of Cardiology (ESC) and the European Atherosclerosis Society (EAS). European Heart Journal.2011;32.p.1769-1818.

15. Nuhu A, Ruhul A, Asaduzzaman K, Ismot A, Mi JS, Min WL, et al. Comparative Effects of Oyster Mushrooms on Lipid Profile, Liver and Kidney Function in Hypercholesterolemic Rats. The Korean Society of Mycology. Mycobiology 2009.37(1) : 37-42.

16. Aida F, Shuhaimia M, Yazid M, Maaruf A. Mushroomas a Potential Source of Prebiotics: a review. Trends in Food Science and Technology. 2009;20:567-575.

17. Dwi E. Pengaruh Minuman Fungsional Mengandung Tepung Kedelai Kaya Isoflavon dan Serat Pangan Larut terhadap Kadar Total Kolesterol dan Trigliserida Serum Tikus Percobaan.Jurnal Teknologi dan Industri Hasil Pertanian Volume 12.2007 .

18. Inga S, Gaby $\mathrm{K}$, Annette $\mathrm{M}$, Ulrich $\mathrm{K}$, Ralf G, Andreas H. Lipid lowering effects of oyster mushroom (Pleurotus ostreatus) in humans. Journal of Functional Foods. 2011. 3:17-24.

19. Santoso F, Priyo W, Elly W. Uji aktivitas antihiperkolesterol ekstak $\beta$-glukan larut alkali jamur tiram putih (Pleurotus ostreastus (Jacq.) P.Kumm) pada hamster hiperkolesterolemia. Universitas Muhammadiyah Prof. Dr. Hamka. 2012.

20. Mowsumi F, Choudhury M. Oyster Mushroom: Biochemical and Medicinal Prospects. Bangladesh J Med Biochem 2010; 3(1): 23-28.

21. Yunita H. Pengaruh Waktu Perebusan terhadap Kadar Senyawa B-glukan dari Ekstrak Air Jamur Tiram Putih (pleurotus ostreatus) dan Uji Aktivitas Antioksidannya dengan Metode DPPHs. Fakultas Kedokteran Dan Ilmu Kesehatan Uin Syarif Hidayatullah Jakarta.2012.

22. Byun J, Han Y, Lee S. The Effects of Yellow Soybean, Black Soybean, and Sword Bean on Lipid Levels and Oxidative Stress in Ovariectomized Rats. Int. J. Vitam Nutr Res. 2010. p. 97 - 106.

23. Haring R, Baumeister S, Volzke H, Dorr M, Felix $\mathrm{S}$, Kroemer $\mathrm{H}$, et al. Prospective Association of Low Total Testosterone Concentration with an Adverse Lipid Profile and Increased Incident 
Dyslipidemia. European Journal of Cardiovascular Prevention \& Rehabilitation. 2011, 18(1):86-96.

24. Lee, J Lee, Cho, Stampfer, Willett, Kim, E Cho. Overall and abdominal adiposity and hypertriglyceridemia among Korean adults: the Korea National Health and Nutrition Examination Survey 2007-2008. European Journal of Clinical Nutrition 67, 83-90, January 2013.

25. Kurt M, Ripple T, Michael W. Craig I. The Impact of Garlic on Lipid Parameters: a Systematic reviewew and Meta-analysis. Nutrition Research Review. 2009.

26. Vijayakumar R, Nalini N. Piperine, an active principle from Piper nigrum, modulates hormonal and apo lipoprotein profiles in hyperlipidemic rats. J Basic Clin Physiol Pharmacol. 2006;17(2):71-86.

27. Shreya S, Gaurang B, Satbeer D, Priyanshi V, Kajal C, Khyati A, et al. Effect of piperine in the regulation of obesity-induced dyslipidemia in highfat diet rats. Indian J Pharmacol. 2011 May-Jun; 43(3): 296-299.

28. Mann J, Stewart A. Essential of Human Nutrition Third Edition. USA : Oxford University. In press 2007.p.637.

29. Iva T, Djoko W, Dian H. Pengaruh Pemberian Diet Tinggi Karbohidrat Dibandingkan Diet Tinggi Lemak terhadap Kadar Tigliserida dan HDL Darah pada Rattus novergicus galur wistar. Jurnal Kedokteran Brawijaya, Vol. XXII, No.2, Agustus 2006.

30. Carol D, Rachel K. Energy. In : L. Kathleen, Sylvia Escott-Stump, editors. Krause's Food and Nutrition Therapy. $12^{\text {th }}$ ed. Philadelphi,USA-Saunders Elsevier; 2008.p.24

31. Mayes PA. Sintesis, Pengangkutan, dan Penyimpanan Lipid. Dalam: Murray RK, Granner DK, Mayes PA, Rodwell VW, editor. Biokima Harper. 27th ed. Jakarta: EGC; 2009. Hal: 225-239.

32. Neyrinck, Possemiers, Verstraete, De Backer, Cani, Delzenne. Dietary modulation of clostridial cluster XIVa gut bacteria (Roseburia spp.) by chitin-glucan fiber improves host metabolic alterations induced by high-fat diet in mice. Journal of Nutritional Biochemistry. Oktober 2012.

33. Elkhoury, Cuda, Luhovyy, Anderson. Beta Glucan: Health Benefits in Obesity and Metabolic Syndrome. Journal of Nutrition and Metabolism.2012.

34. Thompson D, Karpe F, Lafontan M, Frayn K. Physical activity and exercise in the regulation of human adipose tissue physiology. Physiol Rev.2012. 